\title{
ПУТИ ПОВЫШЕНИЯ ЭФФЕКТИВНОСТИ РАЗВИТИЯ ГРАДОСТРОИТЕЛЬНОЙ ДЕЯТЕЛЬНОСТИ В РЕСПУБЛИКЕ ДАГЕСТАН
}

\author{
(c) 2019 Шабанова Мадина Мухидиновна \\ Заведующая кафедрой ГиМУ \\ Дагестанский государственный технический университет, Респ. Дагестан, Махачкала
}

(c) 2019 Шабанов Рашид Мухидинович

Начальник УСЗН в муниципальном образовании «город Буйнакск», Респ. Дагестан

\section{(c) 2019 Дусилаева Хажибати Магомедовна}

преподаватель

Республиканский промышленно-экономический колледж, Респ. Дагестан, Махачкала

В статье рассмотрена градостроительная деятельность в Российской Федерации и Республике Дагестан. Анализирована ситуация в сфере градостроительства

Ключевые слова: градостроительная деятельность, урбанизация, миграция.

Анализ тенденций территориального развития градостроительной деятельности в Российской Федерации позволил выявить тенденции, характерные для ее современного развития:

- в России усиливается неравномерность расселения населения вследствие развития процессов урбанизации;

- идет трансформация системы расселения, созданной в индустриальную советскую эпоху, когда треть всех городов создавалась при вновь построенных заводах;

- миграционные процессы в основном идут в направлении крупных городских агломераций центральных городов России в европейской части страны, что приводит к их разрастанию и усилению диспропорций территориального развития;

- значительно сокращается количество сельских поселений, вследствие оттока населения и отсутствия градостроительной деятельности на этих территориях.

Аналогичные тенденции характерны и для Республики Дагестан:

- более $80 \%$ населения проживает на территории прикаспийской низменности, в том числе около $22 \%$ в районах расположенных вблизи городских округов и $58 \%$ в самих городских округах;

- происходит миграция населения с горной части республики на низменную;

- к минимуму сведено государственное регулирование территориального развития и градостроительной деятельности в муници- пальных образованиях в сельских местностях и горных районах.

Правда в последние годы активизировалась работа по подготовке и утверждению генеральных планов и правил землепользования и застройки городских округов и поселений. На сегодняшний день:

- разработаны и утверждены схемы территориального планирования всех 42 муниципальных районов РД;

- разработаны и утверждены генеральные планы в 9 из 10 городских округах республики. В Южно-Сухокумске генплан находится на стадии разработки;

- из 707 поселений разработаны 260 генеральных планов, из которых для 191 поселений генпланы утверждены;

- в 8 из 10 городских округов республики утверждены правила землепользования и застройки (ПЗ3);

- из 707 сельских поселений правила землепользования и застройки разработаны для 395 поселений, из которых 321 утверждены [1,2].

Итоги мониторинга позволили выявить ключевые проблемы территориального развития республики. Эти проблемы должны лечь в основу процесса реализации республиканских и муниципальных приоритетных проектов.

Практически отсутствуют проекты по развитию инфраструктуры села. Водоснабжение проводится силами самих жителей, канализация отсутствует вовсе. В большинстве горных сел проблемы с электричеством. Не везде налаже- 
но газоснабжение. Основные связующие дороги республиканского значения асфальтированы, но дороги до самих сел гравийные текущий ремонт которых производится силами самих жителей.

Увеличение численности населения городов, за счет миграции сельских жителей, приводит к перенасыщенности городов и неравномерному распределению человеческого ресурса. В качестве примера можно привести город Детройт США. С 30x годов прошлого века город рос и развивался за счет увеличения мощностей машиностроительной промышленности. Таких гигантов как Дженирал Моторс. Нельзя сказать, что для Детройта GM была градообразующим предприятием, но свое прозвище «Город Моторов» крупнейший населенный пункт Мичигана получил не зря. Располагающиеся рядом штаб-квартиры «Форд Моторс» и «Крайслер» наряду с GM навсегда закрепили за Детройтом репутацию столицы мировой автомобильной промышленности. Однако сейчас Детройт - это город противоречий и упадка, где витрины роскошных магазинов и небоскребы соседствуют с разрушенными зданиями и заброшенными заводами. Численность населения сократилась с 1850000 в 1950 году до 680000 в 2014 году, почти в три раза. К такому состоянию города привело банкротство Дженирал Моторс.

Учитывая подобные примеры, напрашивается вывод, что при планировании градостроительства необходимо учитывать экономический фактор как один из основных.

Для повышения эффективности управления градостроительным развитием территории республики необходимо развивать не только городские округа, но и сельскую местность.

Эту социально значимую для региона задачу успешно решает ОАО «Дербентский завод игристых вин». Масштабные проекты благоприятно сказываются на рынке труда, создаются новые рабочие места и обеспечивают население постоянной работой. В 2012-2013 завод уже посадил виноград на 1300 гектарах земли в селениях Зиль, Дарваг и Мугарты. В 2014 на 2000 гектарах селения Геджух.

Сегодня, в южном Дагестане, продолжается посадка современных виноградных саженцев на полях расположенных около поселка Геджух. В 2014 году полностью завершили посадку на 500 гектарах арендованных земель у поселка, и оснастили их системами капельного орошения.

Это завершающая стадия всех запланиро- ванных работ в поселке, которые ведутся с осени 2013. В целом же было запланирована посадка новых современных виноградников на территории 2500 гектаров с полным оснащением их системой капельного орошения. Работы сопровождаются восстановление всей инфраструктуры виноградарства. Постройки дополнительных искусственных водохранилищ, восстановлением Геджухской плотины, ремонтом дорог.

Следовательно, получается, что один инвестиционный проект, дал толчок для экономического и инфраструктурного развития четырех населенных пунктов Республики.

Подобный подход применим к каждому населенному пункту республики, с учетом географического и геологического положения, климатических условий.

Эти два примера показывают, что градостроительную деятельность нельзя рассматривать как обустройство каждого города в отдельности. Необходимо детальное изучение и разработка генерального плана всего региона с перспективами развития. Генеральный план должен включать в себя и план экономического развития региона.

В настоящее время, план экономического развития разрабатывает Министерство экономического развития РД, а градостроительный план разрабатывается Министерством жилищно-комунального хозяйства РД. Такой подход не позволяет увидеть всю картину целиком. Необходим инструмент (управление и т.п.) который позволит объединить, два плана развития, детально проанализировать и разработать объединенный (полный) план развития Республики Дагестан. Необходим комплексный подход. Такой подход позволит эффективно управлять развитием территории Республики в целом.[3]

На данном этапе встает вопрос, где взять данные министерствам, для анализа и разработки проектов. Конечно на земле. В каждом населенном пункте знают свои плюсы и минусы. Специфику экономико-географического положения, прилегающую территорию, экономический потенциал, историю и достопримечательности. В одном селе может находится исторический памятник, в другом источник с целебной водой и т.П., что позволит организовать туристическую базу или санаторий.

Как, например в с. Магарамкент, в близи которого располагаются радоновые источники «Кпул-Ятар». На языке местного населения (лез- 
гинский) «Кпул-Ятар» означает «воды от ревматизма». На базе этих источников был создан санаторий-профилакторий, с одноименным названием, который пользуется популярностью не только жителей республики.

Этот проект позволил не только увеличить число квалифицированных рабочих мест, но и развить инфраструктуру. Проведена асфальтированная дорога, радом с санаторием открыт ресторан, с изысканной национальной кухней, сеть магазинов.

Подобные инвестиционные проекты, можно разработать в каждом населенном пункте Республики. Инвесторами и разработчиками могут выступать сами жители. Но зачастую есть идея, но нет возможности. Или наоборот, есть идея, начинается реализация проекта, но сам проект создает проблему для развития территории в целом (строительство дороги, прокладки магистрали и т.п.).

Поэтому должна быть обеспечена увязка территориального развития с общей стратегией социально-экономического развития региона.

На рисунке 1 представлена, предлагаемая нами организационно-экономическая модель территориального планирования и градостроительства в Республике Дагестан, в которой предлагается всю работу по территориальному планированию и градостроительству осуществлять на основе программ социально-экономического

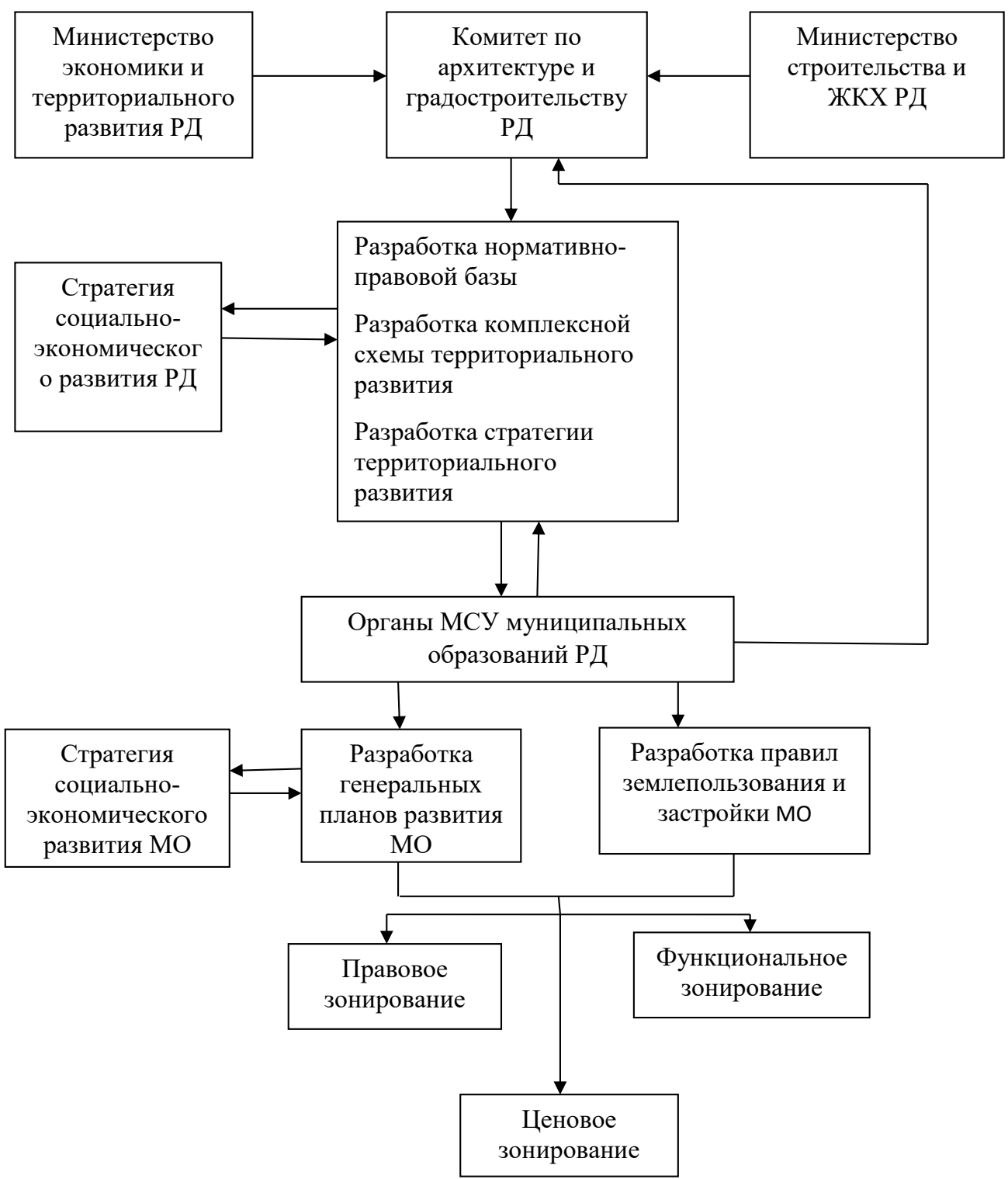

Puc. 1. Организационно-экономическая модель территориального планирования и градостроительства в Республике Дагестан 
развития республики. И в, свою очередь, разработка стратегии социально-экономического развития должна осуществляться на основе детального анализа в территориальном разрезе республики с учетом специфики потенциала каждого населенного пункта (экономического, географического, исторического, кадрового и т.п.). Необходима разработка плана стратегического развития, с указанием реальных точек роста.

Данная работа может быть проделана только при условии тесного взаимодействия с муниципальными образованиями. Вплоть до сельских поселений.

В связи с этим вырисовывается определенная схема взаимодействия. Администрация сельского поселения разрабатывает генеральный градостроительный план поселения с учетом инвестиционного проекта и передает его в муниципальное район. Тот, в свою очередь, обобщает полученную информацию, анализирует и подготавливает генеральный план экономического и градостроительного развития муниципального района, с учетом точек роста, предоставляет его в Комитет по градостроительству и архитектуре РД, который работает в тесном взаимодействии с Министерством экономического и территориального развития РД и Министерством строительства и жилищно-комунального хозяйства РД. В результате, разрабатывается генеральный градостроительный план Республики Дагестан. В действующем генеральном плане Республики Дагестан присутствует карта стратегического развития. Изучив ее, приходишь к выводу, что она составлена только лишь с учетом экономико-географического положения республики.

Мало того, анализ градостроительных планов муниципальных образований РД показывает, что ни в одном из них нет карт, стратегического развития территории муниципального образования. В качестве примера можно привести градостроительный план муниципальное образование городского округа «город Буйнакск». Он включает в себя:

- Карта «Градостроительного планирования» (территориальные зоны);

- Карта «Зоны ограничений от возможных чрезвычайных ситуаций природного характеpa»;

- Карта «Зон действия ограничений по экологическим и санитарно-эпидемиологическим

\section{условиям».}

То есть необходимый минимум градостроительного плана, а стратегического видения нет и нет увязки со стратегиями социально-экономического развития территории.

Этот пример показывает, что муниципалитеты, при большой загруженности другими вопросами, нехваткой финансового обеспечения, не всегда готовы к проявлению инициативы. Выполняется необходимый минимум, без глубокого изучения вопроса.

В связи с этим, напрашивается вывод, что не всегда проявляется инициатива снизу. Необходимо плановое регулирование эффективного управления данного процесса. Должна быть разработана модель управления этим процессом, которая включает в себя, не только продвижения инвестиционного проекта по вертикали вверх. Возникает острая необходимость в постановке задач в данном направлении перед министерствами и ведомствами, а те в свою очередь должны спускать соответствующие решения по вертикали вниз. Необходима смешанная модель управления.

Региональный уровень власти должен активно влиять на разработку нормативно-правовой документации по управлению градостроительством и оказывать регулирующее влияние на подготовку градостроительной документации на уровне муниципалитетов, связывая воедино разнообразные интересы в масштабе региона и входящих в его состав муниципальных образований. Муниципальный уровень влияет исключительно на процесс производства градостроительной документации, так как интересы муниципалитетов по своей природе предельно конкретны и связаны с обслуживанием определенной территории.

Что же касается управления градостроительством на региональном уровне, то исследование статуса органов управления градостроительством в 60 регионах России показало, что - статус учреждений, занимающихся управлением градостроительством в регионах различный (управления, департаменты, министерства), соответственно и положение таких органов в региональной иерархии власти различается; - в общей структуре большинства региональных органов нет понятия «градостроительство»; - в большинстве регионов не рассматривают градостроительство и задачи управления им как приоритетные и произвольно соединяют органы, 
ответственные за управление градостроительством с органами, работающими областях ЖКХ, дорожного хозяйства, развития инфраструктуры, строительного комплекса, транспорта, жилищной политики. Аналогичная ситуация наблюдается и в Республике Дагестан. Очень плохо обстоят дела с управлением градостроительной деятельностью и на муниципальном уровне.

Поэтому на наш взгляд основными условиями обеспечения эффективности системы управления градостроительным развитием муниципальных образований являются:

- использование всех территорий города в соответствии с целями социально-экономического развития территории;

- распределение всей территории муниципального образования на земельные участки на основе градостроительной документации с установленным, в соответствии с Правилами землепользования и застройки территории, разрешением на использование или ограничением этого использования (правовое зонирование);

- выделение на территории города функциональных зон (Деловой центр, жилые микрорайоны, промышленная зона и т.п.) (функциональное зонирование);

- дифференциация территории муниципального образования по стоимости земли в зависимости от ее местонахождения (ценовое зонирование);

- учет всех земельных участков в Государственном кадастре недвижимости и установление прав на их использование.

\section{Библиографический список}

1. Информация о деятельности Министерства строительства, архитектуры и жилищно-коммунального хозяйства Республики Дагестан в 2017 году/ [Электронный ресурс].- Режим доступа: http:// www. minstroy.edag.ru.

2. Материально-пространственная структура среды. Каркас города. [Электронный ресурс].- Режим доступа: http://alyos.ru/enciklopediya/arhitektura_gorodskoj_sredi/materialno_prostranstvennaya_struktura_sredi_ karkas_goroda.html

3. Атуева Энара Бадурсултановна, Дусилаева Хадижат Магомедовна, Шабанова Мадина Мухидиновна Приоритетные направления развития жилищно-коммунального хозяйства // Вестник ДГТУ. Технические науки. 2015. №3. URL: https://cyberleninka.ru/article/n/prioritetnye-napravleniya-razvitiya-zhilischnokommunalnogo-hozyaystva (дата обращения: 06.10.2019). 